$$
\therefore \frac{\text { NIINES AND PETROLEUM BULLETIN }}{\% \quad \text { August } \quad \text { is58 }}
$$

Vol. XVI

No. 8

Exploration activities not mentioned in last month's Bulletin include the following: Walloce MeGregor of Salt Lake City hos, ra rreconnaissance crew in the field ogoin this year. Diamond Alkali is looking for mercury in the Kuskokwim mercury belt. Longyear Drilling $\mathrm{Co}$. is drilling two woll-known prospects for undisclosed clients. Utah Construction and Mining Co. hes resumod work after several years at its Nit. Andrew copper-iron property on Prince of Viales Island. Claims are being staked in all parts of Alaska in numbers almost reminiscent of the gold rush days.

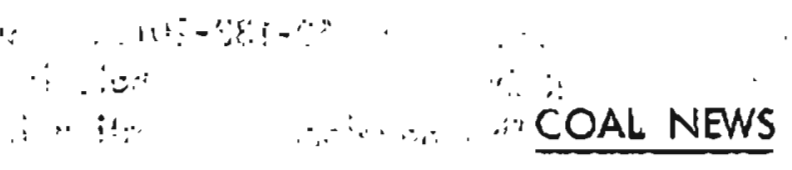

Corteila Coal Corporation of Cordova continues active exploration of coal reserves on Carbon Creak In the Bering Coal Field. weyictor Rhine, president of the corporation, repor's that results are very encouraging as toi the reserves ard mining potential. Geologists and ongineers from the Sumitomo Shoji Corporation of Japen are working actively with Cortella in the exploration of the five mojor beds in the area which have been exposed or locoted by core -drilling and trenching with a smoll bulldozer.

Renewed interest is being shown in the Beluga cod fisids, west of Anchoroge, and in the Arctic coal fields by substantial companies.

\title{
OIL AND GAS NEWS
}

Ten applications for driflling permits were opptoviod by the Division's Petroleum Branch as follows: $\therefore, \because$ Do $11 \%$.

Permit No. 66-59. Pan American Petroleum Corporation 2 Rodoubt Shoal Unit, A.P.1. No. 50-133-20040-01. Surfoce lecation: 701! FSL and 1,628' FWL, Sec. 13, T7N, : RI4W, S.M. Bottom hole location: 840 FNL and 1,650 FWL, Sec. 19, T7N, RI3W, S.M. This wildeat location is in the same guyarter section as the well.

Permit No. 68-60. Shell Oil Company C-43-23 Niddle Ground Shoal, A.P.I. No. 50-133-20129.. Surface locition: 503'. FSL and 7,533! FEL, Sec. 23, T8N, RI3W, S.N. Bottom hole location: 2,510' FSL and 1,180' FEL, Sec. 23, TBN, R13W, S.M. This dovelopmem, Jocation is in the Middle Ground Shoal Field.

Permit No. 68-61: Union: Oil Company of California G-7. Froding Boy Unit, A.P.I.

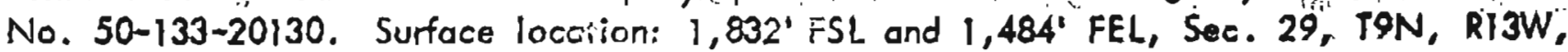
S.M. Bottom hole location: $400^{\prime}$ FSL and 1,100' FWL, Sec. 28, T9N, RI3W, S.M. This development location is in the MeAsthur River Field. 
Permit No. 68-62. Union Oil Company of Colifornia \#-9 Trading Bay Unis, A.P.I. No. 50-133-20131,: Surface location: 756' FSL and 1,139' FWL, Sec. 6, T8N, R13W, S.Mace Bettom hole location: 2,220 FNL and 400' FEL, Sec. 7, T8N, RI3W; S.M. This development location is in the NicArthur River field.

Permit No. 68-63. Union Oil Campany of California "D-10 Trading Bay Unit, A.P.I. No. 50-133-20132. Surface location: 681' FSL and 1,220' FWL, Sec. 6, T8N, RI3W, S.Ni. Bottom hole location: $660^{\prime} \mathrm{FSL}$ and $100^{\circ} \mathrm{FEL}$, Sec. 5, T8N, R13W, S.N. This development location is in the McArthur River Field.

Permit No. 68-64. B.P. Exploration U.S.A., Inc. "1 Sog Delta, A.P.I. No. 50-029-20003. 1,227. FNL and 970' FEL, Sec. 6, TIIN, RI6E, U.N. This exploratory location is on the east side of Prudhoe Bay on the Arctic Ocean coost.

Permit No. $68-65$. Texaco Inc. "TS 3 Trading Bay, A.P.I. No. 50-133-20133.

Surface location: 659' FNL and 2,007' FEL, Sec. 34, TrON, RI3W, S.Ni. Bottom thole location: $670^{\circ}$ FNL and 550' FEL, Sec. 34, TYON, Rl3W, S.N. This development location is in the Trading Boy Field.

Permit No. 68-66. Texaco Inc. "TS 4 Trading Boy, A.P.I. No. 50-133-20134. Surfoce location: 618 FNL and 2,076' FEL, Sec. 34, TION, R13W, S.Mi. Bottom hole location: עa.770'. FStr and 510' FWL, Sec. 34, TION, RI3W, S.M. This development location is in the Jrading Bay Field.

Permik No ... 68-67. Union Oif Company of California A-17 Trading Bay State, A,P,I. Now 50-133-20135. Surface location: 1,608' FSL and 576' FEL, Sec. 4, T9N, RI3W; S.M. Bottom hole location: 1,395' FNL and 285' FEL, Sec. 8, T9N!, RI3W, S.M. This development location is in the Trading Boy Field.

Permit No. 68-68: Standard Oil Company of California WOI 23-7 North Troding Bey, A.P.I. No. 50-133-20136. 2,246' FSL and 2,687' FEL, Sec. 7, TION, RI2W, S.M. This exploration location is northeast of the Trading Bay Field.

DRILLING ACTIVITY (as of July 25, 1968)

\section{Operator}

Atlantic Richfield. Co,

Atlantic Richfield Co.:

Marathon Oil Corp.

Niobil Oil Corp.

Mobil Oil Corp.

Nobil Dil Corp:

Niobil Oilziciorp.

Pan American Petroleum Corp.

Pan American Petroleum Corp.

Pan Amerikoh Permoleum Corp.

Pan Aitiertizan Peatroloum Corp.

Pan American Petroleum Corp.
Well Names \& Numbers

Prudhoe Bay 1

Sag River State 1

Beaver Creek Unit 3

Granite Point State 33-14

Gronite Point State "44-11

Granife Point State "42-23

Moquawkie 2

Granite Point State 17586 "5

Granite Point State 17587

Granite Point State 18742 \#14

Granite Point State $18742 \% 21$

Granite Point State $18742 " 22$
Type Status

E Comp. Gos Woll

E Diflling

D Location.

D. Drilling

D Location

D Drilling

E Drilling:

D Drilling

D Drilling

D Temp. Susp.

D Location

D Drilling 
Operator

Pan American Petroleum Corp.

Pan American Petroleum Corp.

Pan American Petroleum Corp.

Pan American Petroleum Corp.

Pan American Petroleum Corp.

Pan American Petroleum Corp.

Pan American Petroleum Corp.

Pan American Petroleum Corp.

Pan American Petroleum Corp.

Shell Oil Company

Shell Oil Company.

Shell Oil Company

Standard. Oil Co. of Calif.

Standard Oil Co. of Calif.

Texaco, Inc.

Texaco, Inc.

Texaco, Ine.

Texaco, Ine.

Union Oil Co. of Calif.

Union Oil Co. of Calif.

Union Oil Co. of Calif.

Union Oil Co. of Calif.

Union Oill Co. of Calif,

Union Oil Co. of Calif...

Union Oil Co. of Calif.

Union Qil Co of of Calif.

Union Oill Co. of Calif.

Union Oil. Co of Calif.

Union Oil $\mathrm{Co}_{0}$ of Cal if.

Union Oil Co. of Calif.

Union Oil Co. of Calif.

Urion Oil Co. of Calif.

Union Oll Co. of Calif.

Union Oil Co. of Calif.

Union Oil Co. of Calif.

Yukon Services, Inc.

B.P. Exploration U.S.A., Inc.
Weli Names \& Numbers

Granite Point State 18742 \#23

Granite Point State 18742 \#25

Granite Point State 18742 "27

MGS State 17595 \#12

Redoubt Shoal Unit

South NiGS Unit "9

South NiGS Unit "10

South :.1GS. Unit \#11

South NGS Unit \#12

Bachatna Creek \#1.

- MGS C-43-23

NiGS C-33-26

Kustakan Unit 43-30

North Trading Bay A-23-27

Trading Bay TS "]

Trading: Bay TS \#2.

Trading Bay TS \#3.

Trading Bay TS "4

Kenai Unit 43-6A

Kenal Deep Unit 2

Trading Bay State- A-16

Trading Bay State A-17

Trading Bay Unif D-7

Trading Bay Unit: D-8

Trading Bay Unit.D-9

Trading Bay Unit D-10

Trading - Bay Unit G-7:

Trading Bay Unit G-9

Trading:Bay - Unit G-I1

Trading Bay Unit G-12

Trading Bay Unit G-13

Trading, Bay Unit K-3

Trading Bay: Unit K-7.

Trading Boy, Unit. K-8

Trading Boy Unit K-9

Campbell Point \#1

Sag Delta"?
Type Status

Comp. Oil Well

Dritling

D Comp. Oil Woll

D Drilling

E Drilling

D Comp. Oil Well

D Temp. Susp.

D Completing

D Location

E... . Location

D. ". Drilling

D Drilling

E

$E$

E

$D$

$D$

D

D

$D$

$D$

$D$

D

D

D

$D$

D

$D$

$D$

D

$\because D$

D

D

$D$

D

D

D

$\because E$

E
Drilling

Location

Drilling

Drilling

Location

Location

Location

Drilling

Comp. Oll Well

Drilling

Completing

Compi: Oil Well

Lacátion

Drilling :

Drilling

Drilling

Comp.: Oll Woll

Location

Location

Location

Drilling

Drilling

Comp. Oll Woll

Ditlling

Location

"E" indicates an exploratory weil, and "D" a development woll.

PRODUCTION - June 1968 (Gas pressure base 14.65 psi)

Field

Field $\quad$, Oil-3bls Water-Bbls Gos-NCF Wells Prod.

Granite point a

Granite Point $1,104,167 \cdots 23,056 \quad 746,615$

NicArthur River.: $\quad 2,131,889 ; \quad 20,122 ; \quad 582,161$

Middle G̣round Shoal $1,27,4,18 H_{i}$ ii 22,573

Swanson River : $\quad 1,127,009, \ldots 16,147$.

621,486

29 (2)

Cum. Oil

Cum. Cos

Troding Boy:

Total

$\frac{272,695}{5,909,941} \cdot \frac{2,194}{229,092} \cdots \frac{219,429}{4,555,204}$

621,486. $\quad 45$ (2)

$33:(17)$

$14,871,587$

$10,506,378$

$\begin{array}{rrr}17 \text { (1) } & 8,948,105 & 2,484,516 \\ 45 \text { (2) } & 17,256,343 & -7,837,689\end{array}$

$14 .(4)$

$81,788,625 \quad 44,189,020$

$138(26)$

$\frac{1,964,931}{124,829,591}$

$1,829,132$

-3 - 
No. of

Field

Beluga River

Kenai

Kenai Dép

Moquawkie

Sterling

South Barrow

Trading Bory . .

Inaetive Gas Field's

Total Dry Gas

STATE GRAND TOTAL $\overline{5,910,232}$
160,204

$2,714,746$

392,915

13,381

16,905

31,660

21,890
2 (2)

17 (1)

i

1

$3(1)$
752,161

$108,079,558$

993,469

79,220

693,583

$3,661,558$

934

119,439

$12,028,261$

$\overline{229,092} \frac{\overline{3,351,701}}{7,906,905} \quad \frac{\overline{26(5)}}{164(31)} \frac{\overline{124,830,525}}{\frac{126,407,249}{193,253,994}}$

* Dual completions are included as two wells; triple, as three. in June.

Note: Correction in Granite Peint cumulatives for Niay to 13,767,420 bbls and 9,759,763 NiCF. Also changes cumulative State Totals to $118,919,650 \mathrm{bbls}$ and $118,920,293 \mathrm{bbls}$, and $52,291,541$ NCF and 185,347,089 MCF.

11 .

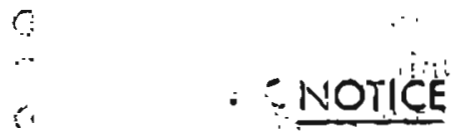

The Alaska Oil and Gas Conservation Committee maintains a mailing list to notify all interested persons of notices of public hearing, conservation orders, etc. Due to changes in the Alaska Statutes during the 1968 Session, the noticos will no longer be given by personal service nor will waivers be solicited. It is the responsibility of all parties who may feel they will be affected by hearings and orders of the Oil and Gas Conservation Committee to have their names and addresses on this mailing list.' To do this, simply request that your name and address bo placed on the Oil and Gas. Conservation Committee Nailing List at the following address:

Executive Secretary

Oil and Gas Conservation. Committee

3001 Porcupine Drive

Anchorage, Alasko 99504

It will be" the responsibility of each party to keep the Committee supplied with his current mailing andress.

se:....usin.

\section{FWPCA WATER QUUALITY PROJECT}

Commissioner Moore of the Federal Water Pollution Control Agency (FWPCA) hos directed that a study be made of placer mining and gravel washing in Alacko to note and compare the changes in stream characteristics caused by such operations. This study is now underway and is being done by a group of Federal and State people including biologists, soil scientists, and representatives of the mining industry. The Division of Mines and Minerals and the University of Alaska Minerals Industry Research lab have each detailed a mining engineer to participate in the study to represent mining intgrests, see. that the group making the study is informed on mining technicolities and problems, and : otherwise see that the study is fair to the mining industry consistent with public interest.

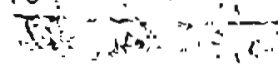

$-4-$ 
To date, waters have been sarifte- above and bclow placer: operations in the Fairbanks District. Nuch more sampling will be done in several locations under varying conditions. Other districts of the State will also be sampled within the next month. A written description of the project showing the purpose, procedures being used, methods for study, sampling methods, etc., should be available for distribution to those requesting it very soon. Conclusions will not be available until this fall, of course.

\section{OIL DISCOVERY}

Much excitement and a leasing rush have been generated by news of the oil discovery at Prudhoe. Bay on the Arctic Slope about 400 miles north of Fairbanks and 150 miles southeast of Pt. Barrow. Plans for moving the oil "south sire reportedly moving ahead.

As a result of the discovery, Governor Walter J. Hickel roquested a meeting of the NORTM Commission. This commission is charged with developing plans for surface transportation to open the Arctic. The meeting is planned for Augusi 22 and 23 in Fairbariks.

\section{STATE GEM AND MINERA!}

We have negtected to report that the last State Legistature passed fows making gold our official State mineral and facie our official State gem. We are not first on these since Califomio hod al ready adopted gotd and Wyerning jede.

Same States hove also adopted officlal rocks:.' Califonnia adopted serpentine some time ago. Readergmight. want to make recommendations to the next Legislature for an official Alaska State rock.

$$
\begin{aligned}
& \therefore \\
& 28 \\
& \therefore: \\
& \text { 江 . }
\end{aligned}
$$

\section{LIST OF GOLD PURCHASERS}

We miv theve on hand at each of our three offices a list of approximately 1200 persons and firms whicb purchrose gold. We rogret that the physical makeup of this list is such that it cannot be copied and distributed; but it is avallable for consultation by all interested parties.

$$
\begin{aligned}
& \text {. } . \\
& \therefore \therefore \\
& \text { E' 1: } \\
& \therefore \because
\end{aligned}
$$

\section{NEW USGS PUBLICATIONS}

The follixing open file reports have been released by the USGS and are availatle for consultation in the Aleskan USGS and Dixision of Mines and Minerals offices. Niaterial from which copies of these open, file reports can ba: mgde at private expense is ovailable in the Aloskan Geotogy Bronch, ... USGS, 345 Middlefield Road, Niento Perk, Cajifornia 94025.

Reconmaissanceiggology, mineral occurrences and geochemical anomoties of the Yentna district, Alaska, by A.L. Clark and C.C. Hewley. 86 pi, including 7 figs. and 18. p. -tabular data.

Netatlic mineral resources map of the Eaird Mountains quadrangle, Alaska, compiled by Edward H. Cobb. 2 p., 1 map, scale 1:250,000. 
Nietallic mineral resources map of the Ambler River quadrangle, Alaska, compiled by Edward H. Cobb. 3. p., I map, scole 1:250,000.

Metallic mineral resources map of the Shungnak quadrangle, Alaska," complled by Edward H. Cobb. 3 p., I map, scale 1:250,000.

Metalif mineral resources map of the Hughes quadrangle, Alaska, compiled by. Edward H. Cobb. 3 p., 1 map, scale 1:250,000.

Mietallic mineral resources map of the Ruby quadrangle, Alaska, compiled by Edward $H_{i, 1}$ Cobb. 5 p., 1 map, scale 1:250,000

Metallic mineral resources map of the Optilr quadrangle, Alaska, complled by

Edward H. Cobb. 3 p., 1 map, scale $1: 250,000$.

Nietallic mineral resources map of the Iditarod quadrangle, Alaska, complled by Edward H. Cabb. 5 p., 1 mop, scale $1: 250,000$.

Netallic mineral resources map of the Medfra quadrangle, Alaska, complled by Edward H. Cabb. 3 p., 1 map, scale 1:250,000.

Metallic mineral resources map of the McGrath quadrangle, Alaska, compiled by Edward H. Cobb. 3 P. 1 map, scale $1: 250,000$

\section{E. AND M.J. METAL NARKET PRICES}

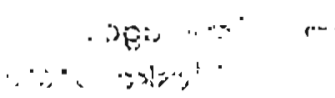

$$
\text { July } 29
$$

Copper, per Ib

Lead, per it

Zinc, per $\mathrm{lb}$

Zing per lb

Nickel, per lb

Platinum, per oz

Niercury, per Flosk

Antimony ore, per unit

Beryllium powder, 98\% (lb)

Chrome ore, long ton

Molybdenum conc, per lib

futaniom ore, per ton

Jungsten, per unit

"Silver, New York, per oz"

Gold, Engelhard, per oz

July 29
$41.7 \zeta$
$12.5 c$
$14.0 c$
141.14
$94.0 c$
$\$ 120-125$
$\$ 500-510$
$\$ 5.00-5.10$
$\$ 54-66$
$\$ 31 .-35$
$\$ 1.62$
$\$ 20-21$
$\$ 43.00$
228.04
$\$ 39.02$

Month Ago

Yoar Ago

38.36

$42 \zeta$

$13 \epsilon$

$14 \%$

$141.4 \xi$

94.004

$\$ 109-114$

$\$ 510-525$

$\$ 5.00-5.95$

$\$ 54-66$

$\$ 31-35$

$\$ 1.62$

$14 c$

146

154.54

$85.25 \%$

$\$ 109-112$

$\$ 472-482$

$\$ 5.20-6.20$

$\$ 54-66$

$\$ 31-35$

$\$ 20-21$

$\$ 1.62$

$\$ 43.00$

$\$ 21-24$

244.60

$\$ 41.30$

* Lowest buying price reported by Engelhard Industrias at which offers can be obtoined for delivery at Newiark, N. 